\title{
SEDIMENT TRANSPORT IN THE BASIN OF PULAU BAAI PORT, BENGKULU
}

\author{
D.K. Mihardja ${ }^{1, *}$, Supiyati $^{2}$, and T Suprijo ${ }^{1}$ \\ 1) Department of Oceanography, Faculty of Earth Sciences and Technology, \\ Bandung Institute of Technology \\ LabTek XI, $1^{\text {st }}$ floor, Jl. Ganesha No.10, Bandung 40132, Indonesia \\ 2) Department of Physics, Faculty of Mathematics and Natural Sciences, Bengkulu University \\ e-mail:dkm@geoph.itb.ac.id
}

\begin{abstract}
The 2D horizontal model has been simulated to investigate a sedimentation and erosion pattern in the basin of Pulau Baai port - Bengkulu Sumatera. The model was verified with observed data from the Indonesian Research Center for Marine Geology (Arifin et al., 2001). The simulation results of the hydrodynamic model shows a good agreement with the observed data. In regard to the elevation of sea level, the difference between simulation and the observed data is about $4.6 \mathrm{~cm}$, giving averaged error of about $2.93 \%$, and the difference in velocity is $6.8 \mathrm{~cm} / \mathrm{s}$ or in the order of error of about $20.1 \%$. The results of the model on sediment transport qualitatively show comparable values to the observed ones, although in some parts of the area, the model is still to be adjusted. Simulation results show that the strong current occurs in the harbor channel during the time of spring flood tide with a speed of about $95.4 \mathrm{~cm} / \mathrm{s}$, while the ebb current is $54.1 \mathrm{~cm} / \mathrm{s}$. The results of the model on sediment transport show that the erosion area occurs in the northeastern part of the basin and sedimentation takes place in the southwestern to southeastern of the channel. The channel port is generally eroded, and sedimentation occurs in the mouth and the western part of offshoreward of the channel, and erosion is identified in the eastern part of the offshoreward of the channel.
\end{abstract}

Keywords: Sediment transport, Tidal current, Numerical model, Pulau Baai port Bengkulu, Sumatra

\section{INTRODUCTION}

Pulau Baai port Bengkulu is located at the west coast of Sumatera having geographical coordinate of $102^{\circ} 16^{\prime} 00^{\prime \prime}$ to $102^{\circ} 18^{\prime} 30^{\prime \prime} \mathrm{E}$ and from $03^{\circ} 53^{\prime} 00^{\prime \prime}$ to $03^{\circ} 55^{\prime} 30^{\prime \prime} \mathrm{S}$ (Fig. 1). The port has important economic role for Bengkulu province and its surroundings. The port has navigation problem due to heavy sedimentation in its basin and channel. For example, sedimentation rate along the coast line of the port reaches $600,000-800,000 \mathrm{~m}^{3} \mathrm{year}^{-1}$ (PELINDO II, 2002), so that for the maintenance of navigation the port's channel need to be frequently dredged, which is very costly. Information on sedimentation and erosion pattern in the channel and basin of the port is needed for the effectiveness and efficiency of the dredging. This information can be obtained from the field measurements and or numerical model. This paper describes the results of numerical model simulation of sediment transport caused by tidal current in the channel and basin of the port of Bengkulu.

\section{MATERIALS AND METHODS}

\section{Hydrodynamics model equation}

Current circulation due to tide in the coastal waters can be formulated by model equation as described below (Koutitas, 1988):

The continuity equation for incompressible fluid is formulated in (1):

$\frac{\partial \varsigma}{\partial t}+\frac{\partial(\bar{u} h)}{\partial x}+\frac{\partial(\bar{v} h)}{\partial y}=0$

The momentum equation in $\mathrm{x}$ and $\mathrm{y}$ coordinate is written:

$\frac{\partial \bar{u}}{\partial t}+\bar{u} \frac{\partial \bar{u}}{\partial x}+\bar{v} \frac{\partial \bar{u}}{\partial y}=-g \frac{\partial \zeta}{\partial x}+\left(\frac{-\tau_{b x}}{\rho h}\right)+A_{h}\left(\frac{\partial^{2} \bar{u}}{\partial x^{2}}+\frac{\partial^{2} \bar{u}}{\partial y^{2}}\right)$ 


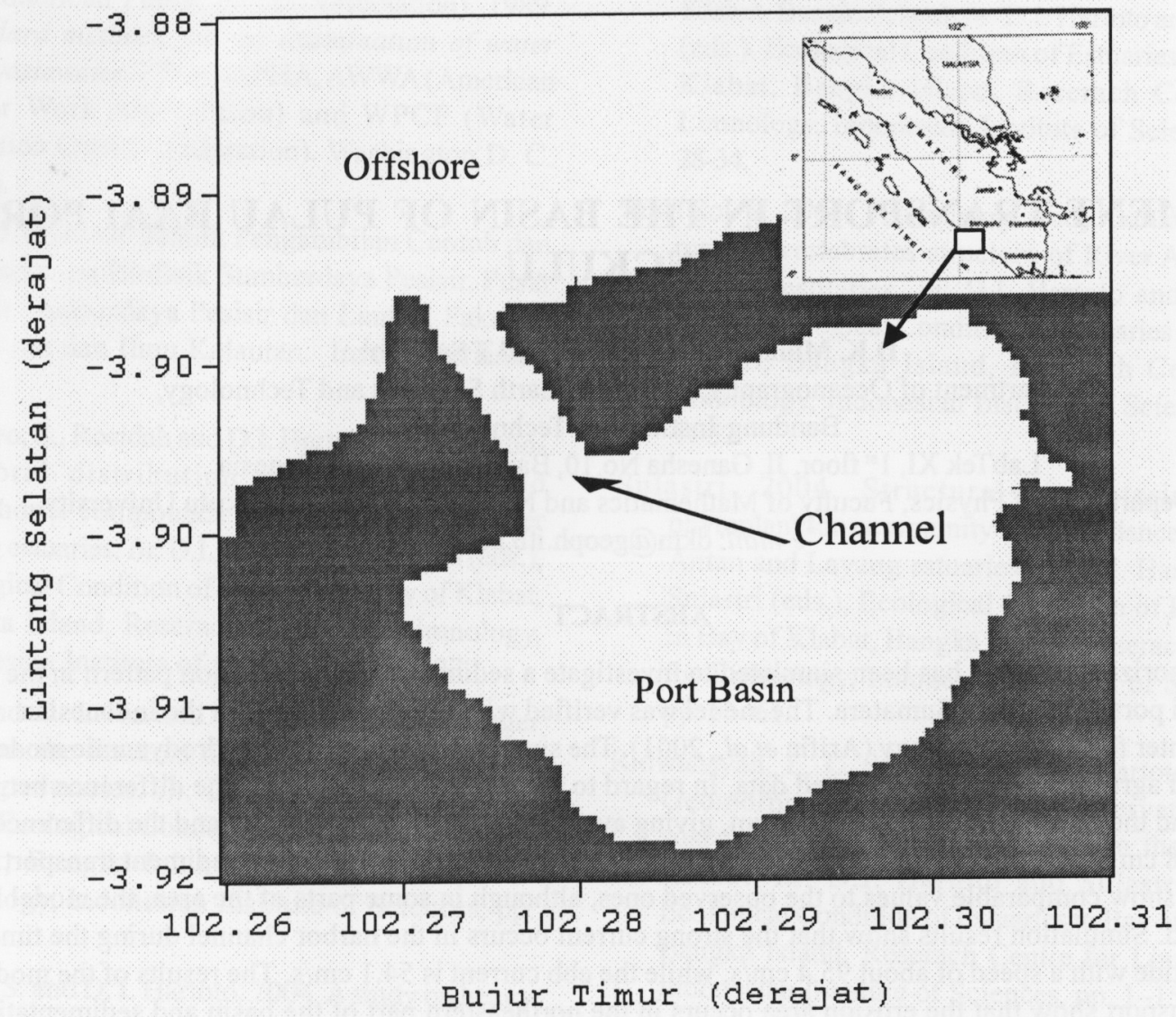

Figure 1. Location of model area (adapted from: Arifin et al., 2001)

$\frac{\partial \bar{v}}{\partial t}+\bar{u} \frac{\partial \bar{v}}{\partial x}+\bar{v} \frac{\partial \bar{v}}{\partial y}=-g \frac{\partial \zeta}{\partial x}+\left(\frac{-\tau_{b y}}{\rho h}\right)+A_{h}\left(\frac{\partial^{2} \bar{v}}{\partial x^{2}}+\frac{\partial^{2} \bar{v}}{\partial y^{2}}\right)$

Where $\overline{\mathrm{u}}$ and $\overline{\mathrm{v}}$ are depth averaged velocities $\left(\mathrm{ms}^{-1}\right)$ that defined as:

$\bar{u}=\frac{1}{h} \int_{-h_{0}}^{\varsigma} u d z ; \quad \bar{v}=\frac{1}{h} \int_{-h_{0}}^{\varsigma} v d z$, and $\varsigma$ is sea level elevation $(\mathrm{m}), \mathrm{h}$ actual depth $(\mathrm{m})$ which defined by $h=h_{0}+\varsigma, h_{0}$ averaged depth or the height of mean sea level $(\mathrm{m}), \tau_{b x}$ and $\tau_{b y}$ are bottom stresses $\left(\mathrm{m}^{2} \mathrm{~s}^{-2}\right)$ that formulated by:

$\tau_{b x}=\rho r \bar{u} \sqrt{\bar{u}^{2}+\bar{v}^{2}}$, and

$\tau_{b y}=\rho r \bar{v} \sqrt{\bar{u}^{2}+\bar{v}^{2}}$

Sediment transport model and change of sea bed morphology equations

Koutitas has defined the relationship of total sediment transport $\left(\mathrm{q}_{\mathrm{t}}\right)$ as a sum of suspended and bed load transports, i.e. $\mathrm{q}_{\mathrm{t}}=\mathrm{q}_{\mathrm{s}}+\mathrm{q}_{\mathrm{b}}$, where $\mathrm{q}_{\mathrm{t}}\left(\mathrm{m}^{2 / \mathrm{s}}\right)$ is formulated by:

$\mathrm{q}_{\mathrm{t}}=0.05 \mathrm{U} \frac{\tau_{\mathrm{c}}^{2} \mathrm{C}}{\rho^{2} \mathrm{~g}^{5 / 2} \Delta \rho^{2} \mathrm{D}_{50}}$, and

$\tau_{c}=\rho g U^{2} / C^{2} ; \Delta \rho=\left(\rho_{s}-\rho_{w}\right) / \rho_{w}$

Where $U$ is current speed $(\mathrm{m} / \mathrm{s}), C$ is Chézy coefficient $\left(\mathrm{m}^{0.5} / \mathrm{s}\right), \rho$ water density $\left(\mathrm{kg} / \mathrm{m}^{3}\right), \mathrm{D}_{50}$ diameter of sediment $(\mathrm{m})$, and $\tau_{c}$ bottom shear stress $\left(\mathrm{kg} / \mathrm{m} / \mathrm{s}^{2}\right)$.

The change of sea bed level $\left(\zeta_{b}\right)$ in meter due to total sediment transport is described in equation (7):

$\frac{\partial \varsigma_{b}}{\partial t}+\frac{\partial}{\partial x}\left(q_{t x}\right)+\frac{\partial}{\partial y}\left(q_{t y}\right)=0$

Numerical solutions of equations (1) to (6) can be seen in Koutitas.

The calculation of sedimentation or erosion volume (Vol) in each grid cell model is used the formula in equation (7). 
$\mathrm{Vol}=\varsigma_{\mathrm{b}}(\mathrm{t}) \Delta \mathrm{x} \Delta \mathrm{y}, \varsigma_{b}(t)>0$, for sedimentation and

$\varsigma_{b}(t)<0$ for erosion.

\section{Model design}

Initial values of simulation are assumed for the basin that is in still condition to be $t=0$. It means that the velocities, sea level elevation, sediment transport, and the change of sea bed level are zero at the beginning of the simulation or in mathematical formulation are written as follows:

$\mathrm{u}=\mathrm{v}=0 ; \zeta=0 ; \mathrm{q}_{\mathrm{tx}}=\mathrm{q}_{\mathrm{ty}}=0 ;$ and $\varsigma_{b}=0$ for $\mathrm{t}=0$.

At the open boundary in the hydrodynamics model, sea level elevations are specified using values from ORITIDE for the year 1996, and in the sediment transport model, radiation boundary condition is used. At the close boundary the so called wall boundary condition or no slip condition is applied.

The dimension of model area of Pulau Baai port is $5100 \mathrm{~m} \times 5050 \mathrm{~m}$, and this area is discretized by $102 \times 101$ grid cells of size $50 \mathrm{~m}$, where $d x=$ $d y$.

The simulation of the sediment transport model driven by total tidal current has been done for one year, while the model using residual current of $\mathrm{M}_{2}$ tide as driving force has been simulated for 10 years. Time increment $(\Delta t)$ used in the model is 1 second. Suspended and bed load sediment are assumed as non-cohesive sediment with diameter of $D_{s 0}$ is $0.1 \mathrm{~mm}$.

\section{RESULTS AND DISCUSSION}

\section{Model verification}

A comparison between simulated sea level elevation and observed data reported by Arifin $e t$ al. (2001) shows good agreement, showing small difference of $4.6 \mathrm{~cm}$ or averaged error of about $2.93 \%$ (Fig. 2).

Figure 3 shows that simulated and observed currents generally have similar pattern though there are differences at certain period. The averaged difference between the two is in the order of 6.8 $\mathrm{cm} / \mathrm{s}$ or error about $20.1 \%$. The difference is probably due to the quality of the observed data which shows inconsistency on the direction of the current as shown in the upper part of Figure 3.

\section{Tidal Current in the Basin}

Generally, the simulated inflow current is faster than the outflow (Table 1). This result is confirmed by the observed data. The maximum current velocity of each tidal period in the basin ranges from 0.36 to $0.95 \mathrm{~ms}^{-1}$, and the highest of the maximum velocity $\left(0.95 \mathrm{~ms}^{-1}\right)$ of inflow occurs during the spring flood tide. The outflow current is about $0.54 \mathrm{~ms}^{-1}$ which occur during the spring ebb tide (Table 1).

\section{Sediment transport and the change of sea bed}

The sea bed morphology change due to tidal circulation that has driven sediment transport is analyzed from the calculation of sedimentation and

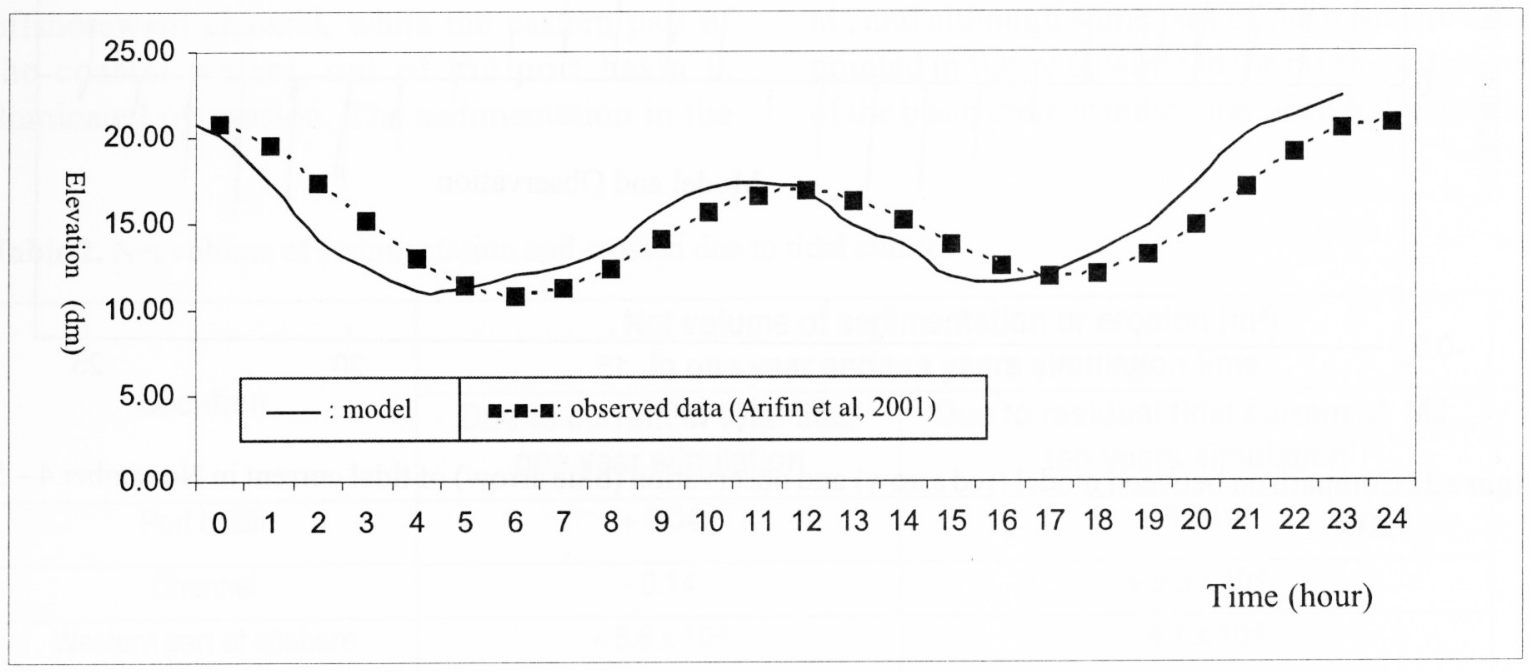

Figure 2. Comparison between model (solid line) and observation (dashed line) of sea level elevation in November $4-5,2001$ 

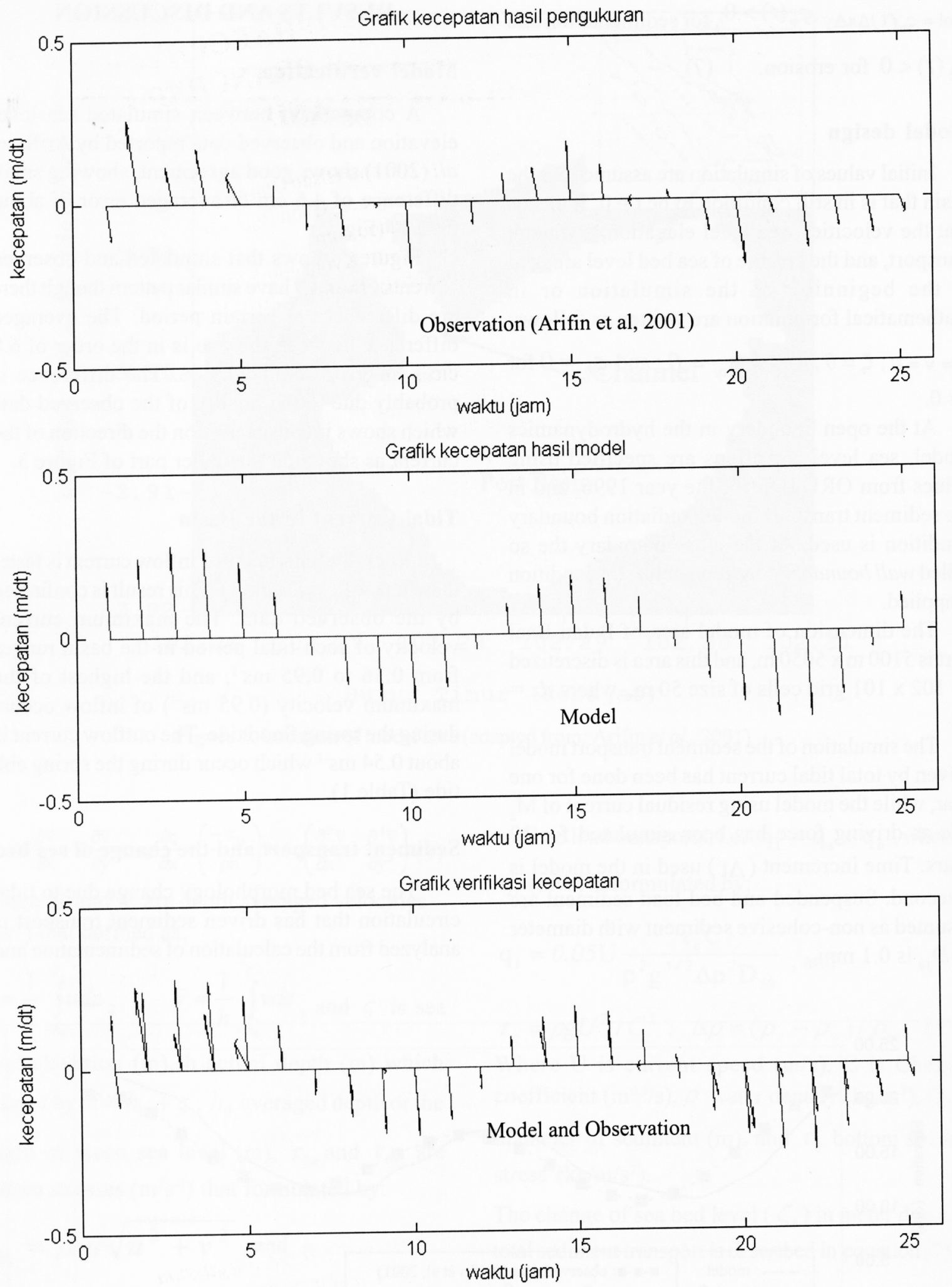

Figure 3. Comparison between model (red arrow) and observation (blue arrow) of tidal current in November 4-5, 2001. 
Table 1. Simulation results of the total tidal current

\begin{tabular}{|c|c|c|c|}
\hline \multirow{2}{*}{ Tidal Condition } & \multicolumn{2}{|c|}{ Maximum velocity $(\mathrm{m} / \mathbf{s})$} & \multirow{2}{*}{ Direction of Current } \\
\cline { 2 - 3 } & Neap & Spring & \\
\hline Maximum of Flood & 0.38 & 0.36 & Outflow \\
Ebb tide & 0.36 & 0.54 & Outflow \\
Minimum of Ebb & 0.53 & 0.83 & Inflow \\
Flood tide & 0.52 & 0.95 & Inflow \\
\hline
\end{tabular}

erosion volumes in the port basin in the certain time interval (one year and ten years).

The calculation result of net volume of the sedimentation and erosion caused by the total tidal current in one year of simulation time, and ten years for residual current of M2 tidal component can be seen in the table 2 . The (-) sign indicates erosion, and $(+)$ indicates sedimentation. Based on this calculation, the basin of Pulau Baai port is dominated by sedimentation. When it is flood time the tidal current flow into the basin with high speed and carries sediment from the offshore area to the basin. In the ebb time the current flow out of the basin more slowly (Table 1), so that the net volume of sedimentation is greater than erosion.

The sedimentation occurs in the southwestern to southeastern part of the basin, and the erosion occurs in the northeastern part (Fig. 4).

Sedimentation also occurs in the mouth of the offshoreward channel, while the eastern part of the coastal waters, out of the port basin is dominated by erosion. The sedimentation in the mouth of the channel is caused by the slow speed the outflow that cannot carry out sediments. Accumulation of sediment in the channel mouth continually causes shallow navigational risk, as has been confirmed by PELINDO report in 2002 and also by Kurniadi (2004).

Simulation with residual current of M2 tidal component (current from Azhar, 2004) as the driving force has the same pattern of sedimentation and erosion, as with the total tide driven transport, except in the western part of the offshore is slightly different as seen in figure 5 , where erosion takes place in the western part, while in the western part as shown in figure 4 is dominated by sedimentation. In the offshore, wave driven long shore current is a dominant factor for sedimentation and erosion (Setiawan et al., 2006).

The results of simulation are qualitatively in accordance with the observed data by Arifin et al., and although some part of the basin are not as pointed in figure 6 , while in the north-eastern part of the basin there is indication of an sedimentation

Table 2. Net volume of sedimentation and erosion due to tidal current

\begin{tabular}{|c|c|c|}
\hline \multirow{2}{*}{ Location } & \multicolumn{2}{|c|}{$\begin{array}{c}\text { Net volume of sedimentation or erosion }\left(\mathrm{m}^{3}\right), \\
\text { in one year and ten years simulation time }\end{array}$} \\
\cline { 2 - 3 } & $\begin{array}{c}\text { Due to current of total tide, } \\
\text { one year simulation }\end{array}$ & $\begin{array}{c}\text { Due to residual tidal current of M2, } \\
\text { ten years simulation }\end{array}$ \\
\hline Port basin & +0.04 & $+3 \times 10^{-6}$ \\
\hline Channel & -0.14 & $+5.3 \times 10^{-5}$ \\
\hline Western part of offshore & $+5.6 \times 10^{-6}$ & $-4.7 \times 10^{-8}$ \\
\hline Mouth of Channel & +0.05 & $+1.2 \times 10^{-5}$ \\
\hline Eastern part of offshore & $-1.1 \times 10^{-5}$ & $-7.2 \times 10^{-8}$ \\
\hline
\end{tabular}




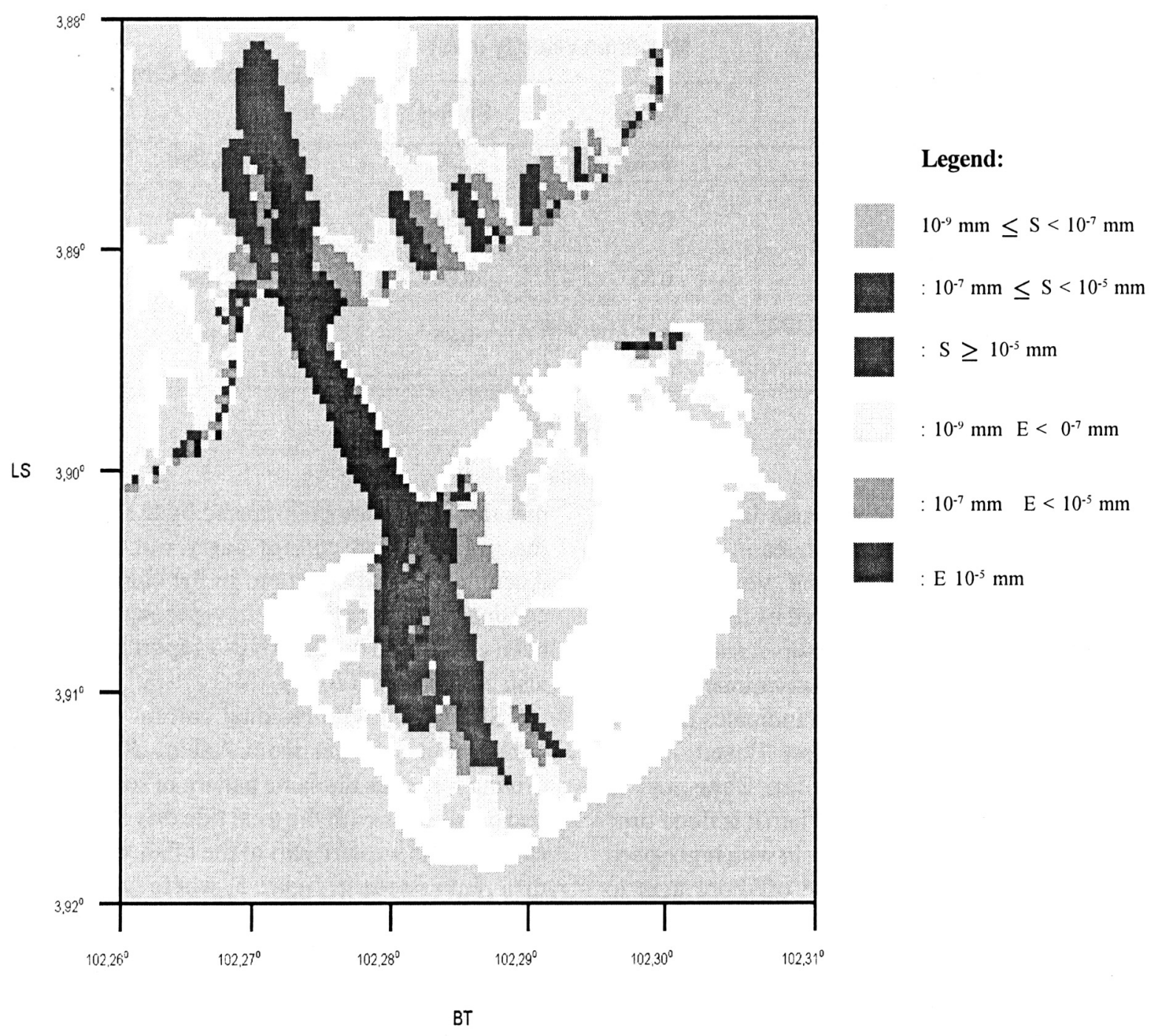

Figure 4. Erosion and sedimentation pattern in the basin of port due to total tidal current for one year simulation time

area whereas model results show an area of erosion.

The difference between the model and observation is probably caused by the use of the formula of $\mathrm{q}_{\mathrm{t}}=\mathrm{q}_{\mathrm{s}}+\mathrm{q}_{\mathrm{b}}$ where the critical shear stress $\left(\tau_{c r}\right)$ is not controlled because the observed data are very limited. By using only tidal current as driving force for sediment transport in the model might be another explanation for the difference.

\section{CONCLUSION}

The results of simulation of hydrodynamics model is well verified by the observation made by
Arifin et al. (2001), especially in sea level elevation with the difference between model results and observation is only $4.6 \mathrm{~cm}$ or error in order of 2.93 $\%$, while the difference in current velocity is 6.8 $\mathrm{cm} / \mathrm{s}$ or error in order of $20.1 \%$.

Maximum velocity produced by model is indicated in the channel of port with a value of $95.4 \mathrm{~cm} / \mathrm{s}$ occurred when flood time of spring tide while in ebb time of the spring is $54.1 \mathrm{~cm} / \mathrm{s}$.

The simulated sediment transport in the basin Pulau Baai port is qualitatively comparable to observed data (see Arifin et al.). Erosion processes take place in the navigation channel and the eastern part of offshore, while sedimentation areas are identified in the mouth of channel and offshoreward 


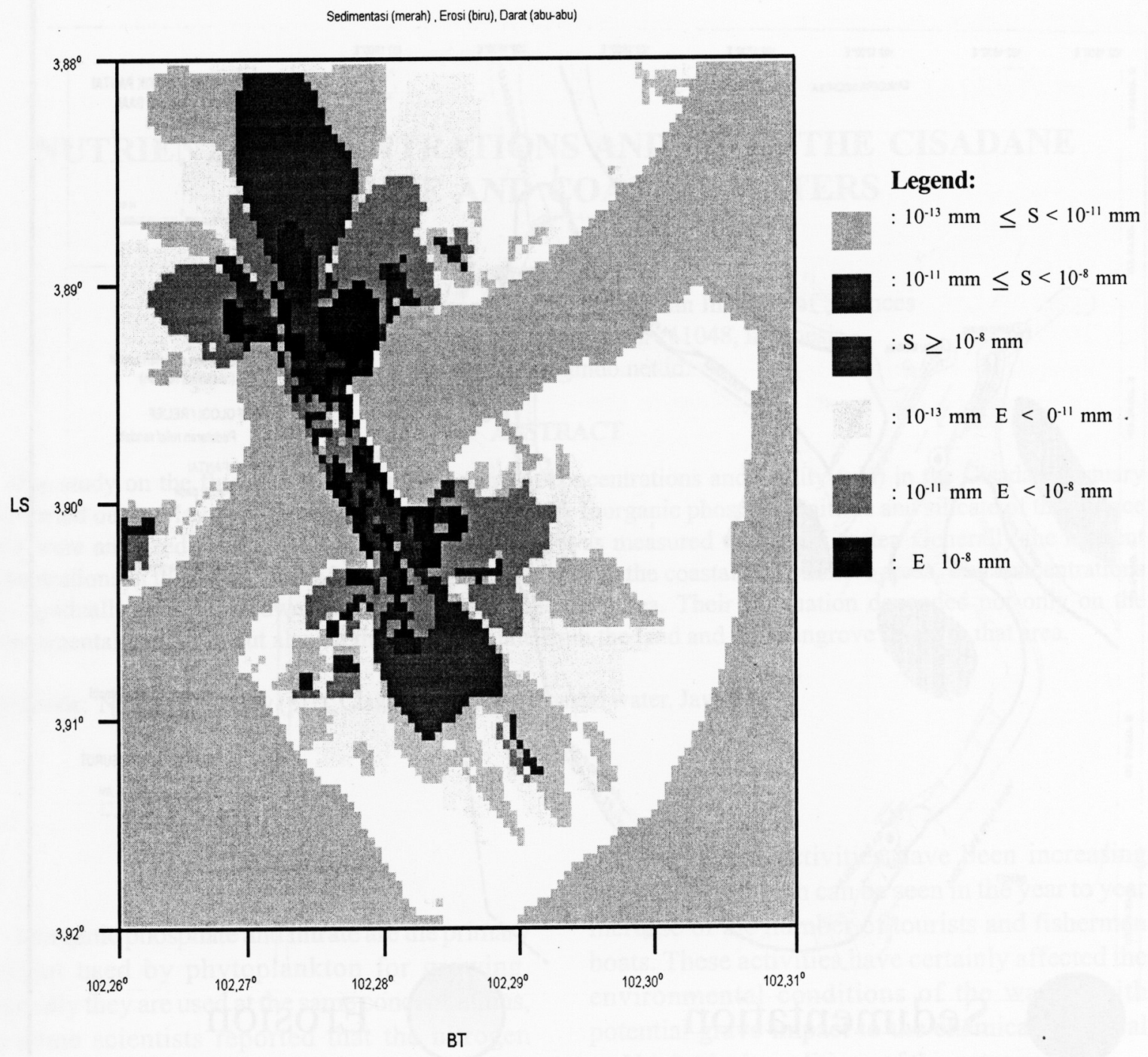

Figure 5. Erosion and sedimentation pattern due to residual tidal current of $M 2$ for ten years simulation time.

of the western part of the coastal waters of Pulau Baai port.

Based on the simulated model results of sediment transport it is suggested to continue the study by both model simulation and observation because sedimentation rate in the port basin of Pulau Baai is relatively high and very costly for an annual dredging, so that why actually sediment transport in the area should be investigated in more detail. 


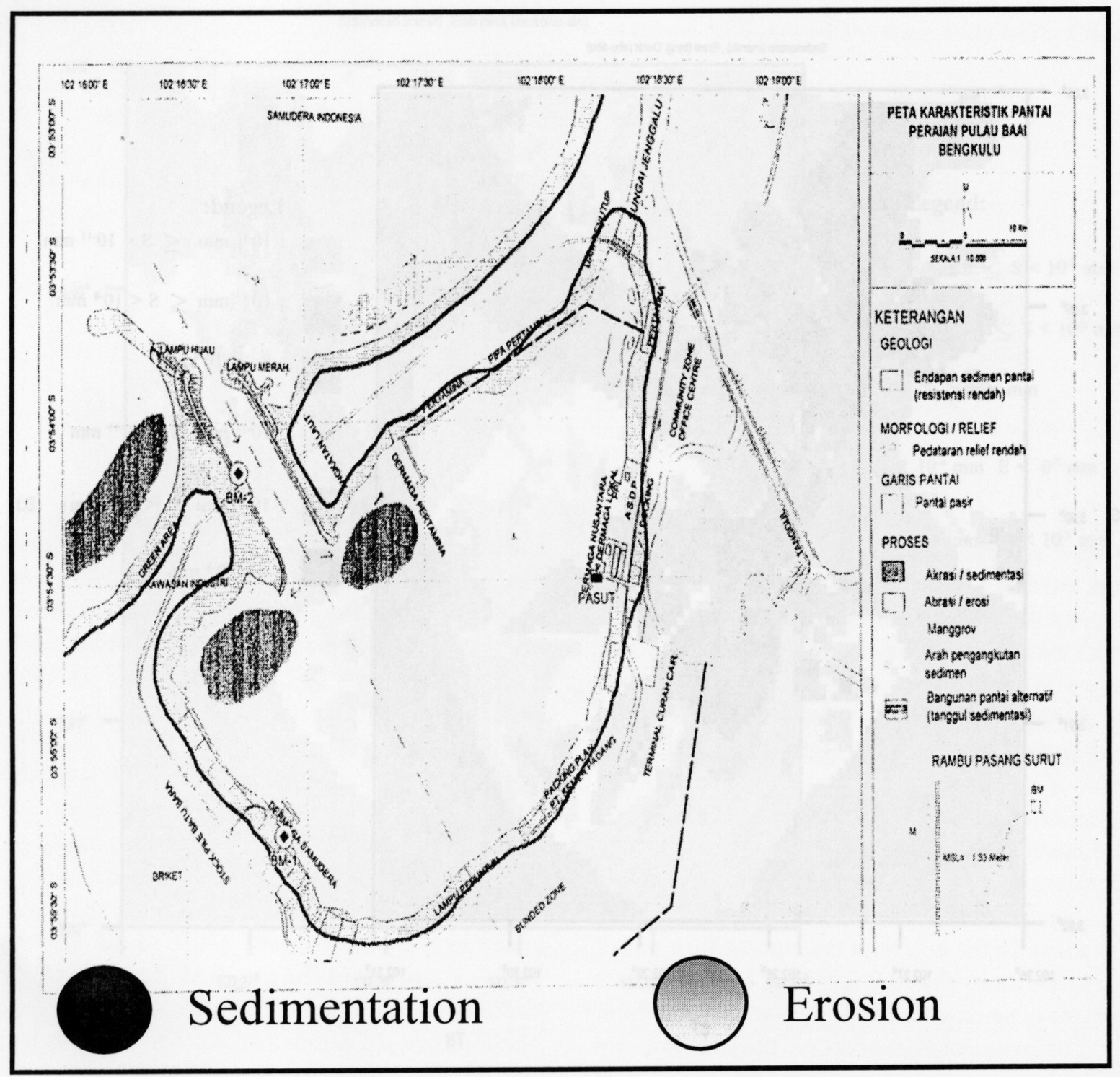

Figure 6. Map of sediment distribution in the port basin of Pulau Baai (Arifin et al., 2001)

\section{REFERENCES}

Arifin, L., Y. Darlan, J.P., Hutagaol, M. Hanafi, Supriadi. 2001. Kajian Proses Sedimentasi untuk Alur Transportasi Batubara di Pulau Baai, Bengkulu Propinsi, Bengkulu, Pusat Penelitian dan Pengembangan Geologi Kelautan, Bandung.

Azhar, M. 2004. Studi Dinamika Pasang Surut di Pulau Baai Bengkulu, Tugas Akhir Program Sarjana, Institut Teknologi Bandung.

Koutitas, C.G. 1988. Mathematical Model in Coastal Engineering, Pentech Press Limited, London.
Kurniadi, N.Y. 2004. Kajian Proses Sedimentasi di Mulut Alur Pelabuhan Akibat Pengaruh Gelombang dan Pasang Surut, Studi kasus pelabuhan Pulau Baai, Tesis Program Master, Institut Teknologi Bandung.

PT (Persero) PELINDO II. 2002. Jasa Konsultasi Dalam Bentuk Tenaga Ahli Perorangan untuk pekerjaan Penelitian Masalah Sedimentasi di Pulau Baai Bengkulu, Bengkulu.

Setiawan, I., T. Suprijo, and D.K., Mihardja. 2006. Pemodelan transport sediment akibat arus yang dibangkitan oleh gelombang di perairan Pulau Baai Bengkulu. J. Geoaplika 1(2): 079-090. 